\title{
The Measurement of Entrepreneurial Outsourcing: Preliminary Scale Development, Dimensionality Assessment, and Construct Validation
}

\author{
Ali Davari',Arash Rezazadeh²
}

\begin{abstract}
Studying the outsourcing concept, as a strategy for efficient and effective business management, has been implemented less in the field of entrepreneurship. Accordingly, the present study aims to develop a measurement instrument for measuring entrepreneurial outsourcing construct utilizing empirical evidence in Iran's telecommunications and automotive industries. Employing a sample of 203 senior managers and executive experts of companies operating in these industries, the gathered data were analyzed using PLS-SEM method. According to our results, the proposed scale of entrepreneurial outsourcing comprises six dimensions: strategic factors, economical factors, technological factors, task specifications, risk relating factors, and entrepreneurial performance. Moreover, the scale enjoys sufficient multidimensionality, reliability, and construct validity in terms of convergent and discriminate validity.
\end{abstract}

Keywords: outsourcing; entrepreneurship; corporate entrepreneurship; entrepreneurial outsourcing; entrepreneurial performance.

\footnotetext{
1,2Faculty of Entrepreneurship, University of Tehran, 16 St., North Kareger Ave.,Tehran, Iran. e-mail: 'ali_davari@ut.ac.ir 


\section{Introduction}

In the present circumstances that organizations deal with issues such as rapid changes in technology, complex competition, rapid growth in the number of new competitors, variety of customer's needs and demands, and general desire to enhance efficiency and productivity, enterprises can benefit competitive strengths through sustaining corporate entrepreneurship, which is determined as a factor of stimulation and strengthening innovativeness, risk taking, and proactiveness (Covin and Miles, 2006; Dess and Lumpkin, 2005). A review on the corporate entrepreneurship literature reveals that although organizations accept the importance of innovation and entrepreneurship in today's competitive word, most of them are not successful in the creation of innovation and entrepreneurship due to the lack of proper infrastructures (Zheng et al., 2009).

On the other hand, partnership and particularly outsourcing is one of the most important issues the organizations are faced with, because companies have limited resources and financially cannot have all technologies within the company. Although reducing costs and freeing up some part of the resources are the most important reasons for outsourcing for profit organizations (Maskell et al., 2007; Saaty and Vargas, 2013), facilitating the service delivery and decentralization reduction are of the main reasons for outsourcing in nonprofit organizations (Martinez-Noya et al., 20I3).

Many organizations and even research institutes nowadays have turned to applying technology and partnerships to provide services in the form of cooperation instead of routine internal activities. Increased awareness of the importance of outsourcing decisions is the result of such organizational changes. In the recent years, managers have been faced to an inevitable and definitive fact, which is about changes in activity environments (Nadkarni and Herrmann, 2010; Dibbern et al., 2004). Emerging markets and global competitors have forced the managers to adopt new management strategies. Although the strategic concepts of outsourcing have been discussed for many years, outsourcing decisions are often adopted based solely on fees and outsourcing is a matter that has been received less attention from the perspective of entrepreneurship.

Outsourcing is a fundamental issue in organizations. However, it is very important due to the risk of losing proprietary knowledge of the organization. The result is increased awareness of the importance of outsourcing decisions. Systematic approaches are vital in outsourcing and have been proposed as one of the critical success factors in outsourcing (Gavious and Rabinowitz, 2003). Nowadays, outsourcing has become a common activity in many organizations. The most important point about outsourcing is that the company or organization that attempts to outsource is responsible for the project success and should specify that whether this affair is rational and profitable or not.

Therefore, according to what has been said and due to the lack of researches in the field of investigating entrepreneurial outsourcing, the present research intends to develop and validate a measurement tool for measuring this concept bridging the gap in research between outsourcing and entrepreneurship.

\section{Literature review}

\section{Outsourcing}

Outsourcing is a decision taken by an organization to provide or sell its assets, human resources and services to a third party, which the contractor must undertake to provide or manage the assets and services listed in the contract in return for a specified income and in a given time (Embleton and Wright, 1998; Javalgi et al., 2009). Theoretical concept of outsourcing refers to the transaction cost theory (Coase, 1937; Williamson, 1979). In this regard, outsourcing as a "make-or-buy" decision refers to the attempts implementing to acquire services from external providers or to handle internal functions with the help of another firms (Grover et al., 1994; Kalaignanam and Varadarajan, 2012). Rather, it can be defined as accomplishing firms' internal tasks by third elements (commercial and service companies outside the organization), building systematic and purposeful collaboration with external partners in order to buy services or share tasks and responsibilities (Willems and Van Dooren, 201 I; Yeboah, 2013). Outsourcing can be as delivery of services or tools for organizations. It can also occur in the case of a manufacturing or service organization. The important thing about outsourcing service organizations is that the vital and important activities of the service organizations should be outsourced scrupulously and carefully, because the nature of these organizations is based on their services and any wrongdoing in outsourcing and reducing the effectiveness of the activities could undermine the nature of goals in the organization (Ndubisi, 2013).

Although there are different theories in the concept of outsourcing, the logic of these definitions are the same and they generally carry the same meaning. The main theories of outsourcing can be cited as follows:

In line with Kakumanu and Portanova (2006), outsourcing is in fact a fundamental change in the structure of tomorrow's international organizations pointing out that there is no more necessity for big companies, governmental agencies, hospitals and major universities - to employ large number of people. Such institutions become organizations that gain 
excellent revenues and dependable results, because they only concentrate on what they are assigned to do, and do things that are exactly related to their organizational goals. They do things that are in the scope of their activities and they are familiar with the intricacies. Other service of such organizations entrusted to external entities.

Mclvor (2005) proposed a conceptual model for the evaluation of outsourcing decisions. The general framework of the model is based on three main criteria: core competencies, capabilities (inside the organization as compared to outside the organization) and expenses (inside the organization as compared to outside the organization). Practical framework in the model is presented in some phases such as core activities, value chain activities, cost analysis and analysis. Holcomb and Hitt (2007) determine a model relating the strategic outsourcing decisions. The model has four phases: I. Preliminary assessment of the business: this phase concerns with the direction of the business and customer preferences. 2. Internal/external analysis: most of the information needed for decision-making is created in this phase and the details of the company and competitor performances are collected. 3. Developing /evaluating the possible options: options for creating inside or outsourcing are analyzed using the first two phases. 4. Optimal strategy selection: the optimal strategy is chosen by using different choices made in phase 3 that provides a significance/competition matrix that focuses on the production technology evaluation. Cox (200I) presents the theory of critical assets about outsourcing. This approach helps with identifying resources in supply chain that are or could be critical and important for businesses. Critical asset is source or combination of sources of supply chain, which have such an importance for the value takeover process that its ownership provides the power of determination and apportion of value across the supply chain for the owner or controller.

Balachandra (2005) proposes the cube model about outsourcing highlighting the role of decision making to capture that which activities can be outsourced. This framework proposes that all projects of producing new products and research and development activities can be considered with three dimensions: market (existing or new), technology (familiar or non-familiar) and investment (low or high). Presenting a model, Hafiz and Essmail (2007) specify four non-core organizational activities for outsourcing. Factors such as ability to compete, knowledge and assets involved in the activities and intended processes, and general and exclusive capabilities of the organization in that field. After an investigation of organizational level of readiness and potential processes and activities for outsourcing, Kamel (2006) concludes that management of maintenance activities has the maximum potential for outsourcing.
Greaver (1999) studying outsourcing from the viewpoint of assets transfer strategies states that not only activities transfer in outsourcing, but also production factors and the right to decision making is often delegated through this collaboration. In this regard, the production factors include employees, facilities, equipment, technology and other assets. Moreover, decision right refers to the main responsibility to make decisions on the components of the transferred activities.

\section{Entrepreneurial outsourcing}

Outsourcing decisions are considered as one of the most complex organizational decisions. Making these complex decisions, especially for entrepreneurial organizations, demands the identification of all affecting factors in both outsourcing and corporate entrepreneurship. Outsourcing benefits on one side and several barriers on the other side make the thorough and accurate evaluation of the outsourcing outputs complex especially from the perspective of entrepreneurship.

Most of the existing literature about entrepreneurial outsourcing defines this variable in terms such as processes, practices and decisions that led to the development and delivery of innovative and new products/services through outsourcing (De Pablos, 2013). Additionally, Murphy et al. (20I2) defined entrepreneurial outsourcing as identification and exploitation of previously unexplored opportunities through outsourcing. Miscimarra and Schwartz (1997) defined outsourcing as a method of exploiting sustainable competitive advantage, innovation, and leadership for organizations through outsourcing. Entrepreneurial outsourcing is a multi-dimensional structure and it can be evaluated from different perspectives.

\section{The dimensions of entrepreneurial outsourcing}

Different dimensions are presented for outsourcing in the literature. Since several studies have examined the outsourcing from variety of perspectives, the considered dimensions of the concept also refers to several factors. For instance, studing outsourcing from the viewpoint of transaction cost theory, highlights the dimension of cost reduction. Different dimensions of entrepreneurial outsourcing derived from various studies are mentioned in the following. 


\section{Strategic factors}

This dimension focuses on core capabilities and the alignment level of activities implementation with mission and strategic goals. Reviewing outsourcing literature (Greaver, 1999; Leavy, 2004; Nadkarni and Herrmann, 2010) arises three main questions: I. How much necessary are these activities to accomplish the organization's mission? Activities that are considered as a part of the main mission of the organization are less likely to outsource.Thus, the greater role performing an activity has in the realization of the mission and strategic goals of the organization, the fewer tendencies to outsource it. 2. How much associated is this activity with intellectual property rights or specialized knowledge of the organization? The existence of intellectual property rights or specialized knowledge in any organization is a major advantage. Hence, the more an activity has relationship with the organization's knowledge or intellectual property, the fewer tendencies to outsource it. 3. How much related are these activities to the organization's core competencies? Outsourcing makes the organization focus on its core activities, and therefore it become more flexible and utilizes its free resources more effectively in order to create value. Thus, activities that are somehow associated with core competencies will be at lower priority level of outsourcing.

\section{Technological factors}

Managers nowadays challenge their organizations with changes and development in the fields of policy, structure, technology and human behavior. One of the most important aspects of change is change in the application and use of technology (Feenstra and Hanson, 1999). Technology has always been a challenging issue for organizations because technological changes may work against the companies and somehow redefine their activities, and lead the companies to make decisions such as outsourcing. Such changes can have a technological nature, which is easy to predict and is usually clear and obvious, and can have a social nature, which is not easy to predict and recognize (De Pablos, 20I3). Therefore, technological factors should be managed in cases of encountering changes via employing a proper strategy. Since not all changes are predictable, having schedules for making decisions in critical situations is a convenient way to manage changes, and outsourcing is one of those decisions.

\section{Task Specifications}

Specifications of outsourced activities are studied in this dimension. Reviewing outsourcing literature (Dibbern et al., 2004; Javalgi et al., 2009; Holcomb and Hitt, 2007) highlights five main questions in relation with the specifications of functions selected for outsourcing: I. How much are the need for using specific technologies or equipment to perform these activities within the organization? While the organization benefits advanced technologies and equipments to perform these activities within the organization, there is little willingness to outsource them. 2. How much is the dependency level of these activities with other activities within the organization? The more the outsourced activity affects other activities, the fewer tendencies to outsource it. 3. How much is the repetition rate of activities? An activity is more likely to outsource when it repeats again and again. In other words, companies have low tendency to provide sources for activities that are done rarely. 4 . How much necessary is organizational control to conduct the activities? In some cases, quality control of services is more essential due to the importance of those activities. The more need to control, the more expenses result from it. Hence, there will be law tendencies to outsource the activity. 5. How much the activity involves in the field of expertise of the organization's activities? Some activities are considered in the field of expertise of other organizations, indicating their precedence to outsource. Internal performing of such activities requires high investment in equipment and assets that are used only to perform them. Therefore, the more the activity is far from the field of expertise of the organization, the more tendencies to outsource it.

\section{Economical factors}

In this dimension, the cost of internal providing of services is compared versus the cost of outsourcing to external sources. Regarding the fact that the more the partners gain benefits from outsourcing, the more tendencies to outsource, companies may emphasize on savings due to various economic factors such as inappropriate financial condition or increasing profitability. Although reducing costs are possible by transferring some parts of functions, the outcome is not appropriate in all situations (Maskell et al., 2007; Arnold, 2000). However, in more cases, specialized institutions have a very low cost due to being specialized and focused in a particular field of activity, and conduct particular functions with lower expenses.

\section{Risk in outsourcing}

Outsourcing strategy has been a useful tool associated with potential risks for organizations. There are studies implemented investigating several risks in connection with this process. The outsourcing literature demonstrates that there is an agreement about the benefits of outsourcing, and both the customer and service provider are more likely to improve their performance after outsourcing (Lee et al., 2003). However, there are concerns about possible damages to the partners resources such as employees if they can't adopt themselves with new circumstances (Carnahan and Somaya, 2013). Employees often show inconvenient 
reactions to outsourced tasks.Additionally, with outsourcing, the company may lose its confidence in operating tasks regarding to the loss of other areas. Moreover, the nature of outsourcing may lead to the creation of dependence on the company's providers and loss of independence. Finally, the outsourced unit is not controllable anymore for the management, resulting the loss of monitoring on outsourced functions (Hall, 2000).

A review on the literature reveals the most important risks for outsourcing partners as follows:

- Service providers can cause damages such as expense increase at any time. With get rid of internal duties, organizations have no authority and they have to pay for this expense increase.

- $\quad$ The provider may not realize the core requirements of the business or specific risks of the business environment. - $\quad$ The provider's employees may have less interest in the assigned job than internal employees may.

- $\quad$ Lack of commitment and loyalty from suppliers, especially in short-term contracts

\section{Entrepreneurial performance of outsourcing}

Organizations can run a complete restructuring through outsourcing and can actually change the current situation. Doing such a considerable action, the staff will know that the management is certain about these changes and it is very likely that the employees contribute to form a new structure in their organizational behavior, resulting in an improvement of performance (Kotabe et al., 2008). Rather, an entrepreneurial organization can use a strategy of delegating some parts of its activities to other institutions through outsourcing as a marketing tool. In this regard, innovativeness, risk-taking, proactiveness, and competitive aggressiveness are highly effective. Through outsourcing, the company demands the required products or services, providing it an opportunity to declare an improvement in quality of its products and services because of cooperation with reputable and qualified companies.

\section{Conceptual model of the research}

According to the above literature review on outsourcing from the perspective of entrepreneurship particularly corporate entrepreneurship and discussed dimensions of the entrepreneurial outsourcing concept, the conceptual framework of the research is presented in figure 1 .

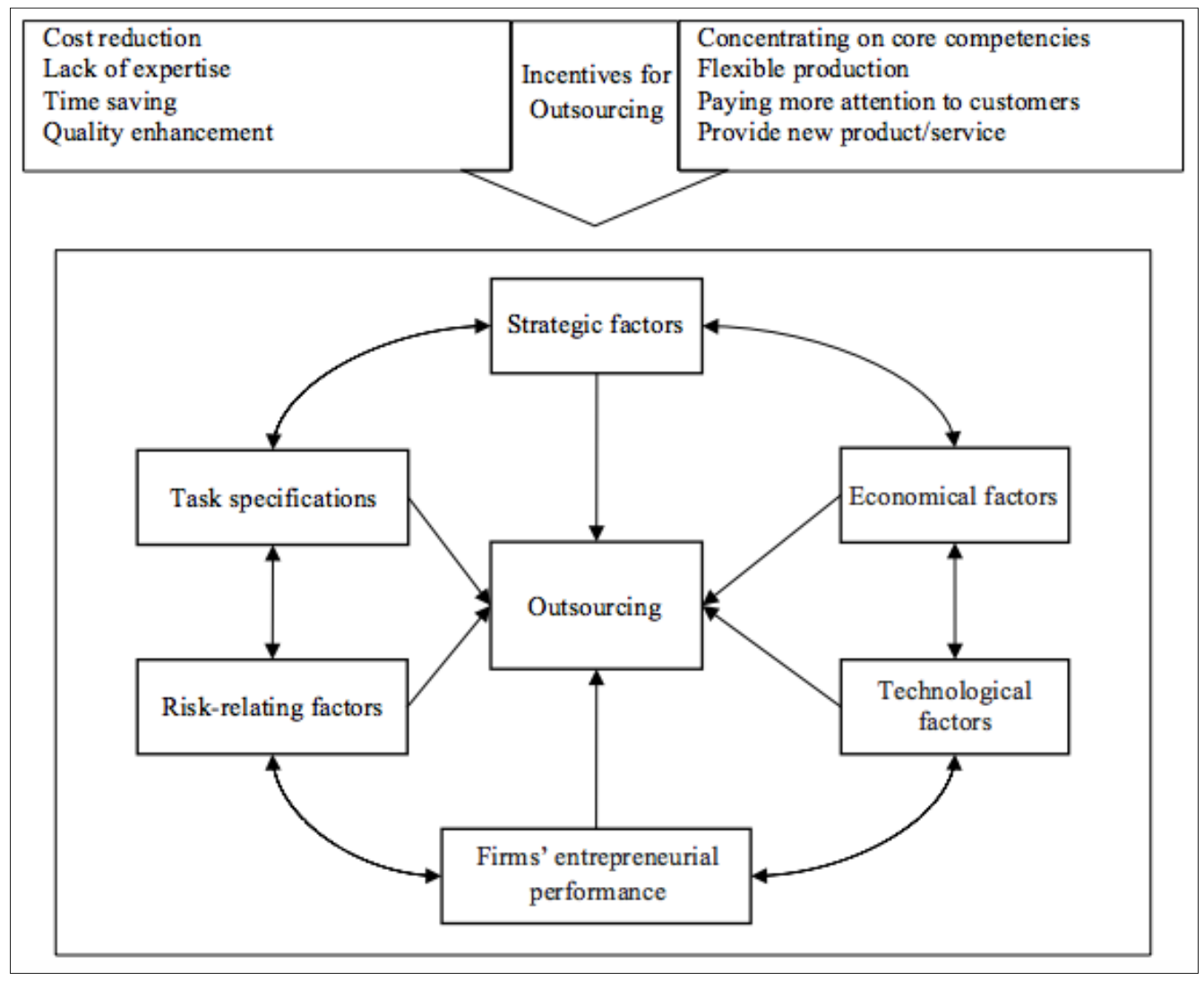

Figure I.The conceptual framework of the research

ISSN: 07 I8-2724. (http://www.jotmi.org)

Journal of Technology Management \& Innovation (C) Universidad Alberto Hurtado, Facultad de Economía y Negocios. 


\section{Method}

\section{Data collection and sample characteristics}

The proposed scale in this research was tested by data gathered from companies operating in Iran's telecommunications and automotive industries. Regarding the fact that these two industries are more active in outsourcing practices, senior managers and executive experts of them were employed to fill the questionnaires containing the items of the entrepreneurial outsourcing scale. The participants were selected via a two-stage approach. In first stage, we removed companies that their outsourcing practices were no longer existed. In the second stage, the remaining sample was purified rather via eliminating of companies that had only one outsourcing practice at that moment. Therefore, the final sample comprising 210 senior managers and executive experts was applied for gathering the data. Since the proposed measurement instrument in this study will be a beneficial tool for companies that engage in outsourcing, we emphasized on this motivation to stimulate the participant to answer the questionnaires. After the filled questionnaires were received, we excluded the flawed questionnaires resulting in 198 final questionnaires that were used for data analyses. Table I provides the descriptive statistics of the sample.

\section{Results}

\section{Item Generation}

We used a review on outsourcing literature from the perspective of entrepreneurship to capture the most important items covering the entrepreneurial outsourcing scale. Our studies revealed that outsourcing reflects in six major dimensions including strategic factors, economical factors, technological factors, specifications of the tasks, risk relating factors, and firms' entrepreneurial performance. Accordingly, we generated detailed items in each dimension considering relevant issues. The final list of items excerpted from questionnaire accompanying the literature used for adopting them is depicted in Table 2 .

\begin{tabular}{|c|c|c|c|}
\hline Gender & Percentage & Age & Percentage \\
\hline $\begin{array}{l}\text { Female } \\
\text { Male }\end{array}$ & $\begin{array}{l}17 \% \\
83 \%\end{array}$ & $\begin{array}{c}30-39 \text { years old } \\
40-49 \text { years old } \\
50 \text { years old \& more }\end{array}$ & $\begin{array}{l}22 \% \\
44 \% \\
34 \% \\
\end{array}$ \\
\hline Education Level & Percentage & $\begin{array}{c}\text { Company's size (No. of employ- } \\
\text { ees) }\end{array}$ & Percentage \\
\hline $\begin{array}{l}\text { Bachelor's degree } \\
\text { Master's degree } \\
\text { Doctoral degree }\end{array}$ & $\begin{array}{c}46 \% \\
48 \% \\
6 \%\end{array}$ & $\begin{array}{c}50 \text { and less } \\
50-250 \\
250-1000 \\
1000 \text { and more }\end{array}$ & $\begin{array}{l}16 \% \\
26 \% \\
38 \% \\
20 \%\end{array}$ \\
\hline Industries & Percentage & Number of Outsourcing practices & Percentage \\
\hline $\begin{array}{l}\text { Telecommunications } \\
\text { Automotive }\end{array}$ & $\begin{array}{l}56 \% \\
44 \%\end{array}$ & $\begin{array}{c}\mathrm{I}-3 \\
7 \text { and more }\end{array}$ & $\begin{array}{l}32 \% \\
48 \% \\
20 \%\end{array}$ \\
\hline
\end{tabular}

Table I. Descriptive statistics of the Sample 


\begin{tabular}{|c|c|c|}
\hline Dimensions & Items & \\
\hline \multirow{5}{*}{$\begin{array}{l}\text { I. Strategic factors (Brown, } \\
\text { 2008; Busi and Mclvor, 2008; Cesa- } \\
\text { roni, 2004; Yang et al., 2007) }\end{array}$} & Concentration on core-competencies & Item I \\
\hline & Access to skilled human resources & Item2 \\
\hline & More flexibility toward environmental changes & Item3 \\
\hline & Outsourcing the complex and challenging functions & Item4 \\
\hline & Paying more attention to customers & Item5 \\
\hline \multirow{3}{*}{$\begin{array}{l}\text { 2. Economical factors (Busi and } \\
\text { Mclvor, 2008; Harland et al., 2008; } \\
\text { Yang et al., 2007) }\end{array}$} & Cost reduction due to not employing new experts & Item6 \\
\hline & Cost reduction due to not Durchasing new equipments & Item7 7 \\
\hline & Cost reduction in implementing subsidiary operations & Item8 \\
\hline \multirow{3}{*}{$\begin{array}{l}\text { 3. Technological factors (Madsen et } \\
\text { al., 2008; Chang and Gurbaxani, 20I2) }\end{array}$} & To develop new functions applying new technologies & Item9 \\
\hline & Learning emoloyees how to utilize new technologies & Item 10 \\
\hline & Technology transfer between partners & Item I I \\
\hline \multirow{5}{*}{$\begin{array}{l}\text { 4. Task specifications (Johnson and } \\
\text { Umesh, 2002; Rawley and Simcoe, } \\
\text { 2010) }\end{array}$} & The extent of preponderance of each task & Item 12 \\
\hline & Task differentiation & Item I 3 \\
\hline & Task diversification & Item I4 \\
\hline & Specialization level of tasks & Item I5 \\
\hline & Complexity level of tasks & Item I6 \\
\hline \multirow{5}{*}{$\begin{array}{c}\text { 5. Risk-relating factors (Domberger } \\
\text { et al., 2000; Tsai et al., 20I2; Kang et } \\
\text { al., 20I2) }\end{array}$} & Failure to protect partners' intellectual capital & Item I7 \\
\hline & The degree of dependence on suppliers & Item I 8 \\
\hline & Loss of control of the outsourced activity & Item 19 \\
\hline & Partners' failure to perform their commitments & Item20 \\
\hline & Limited number of suppliers for outsourcing & Item2I \\
\hline \multirow{5}{*}{$\begin{array}{c}\text { 6. Entrepreneurial performance } \\
\text { (Baloh et al., 2008; Han et al., 2008; } \\
\text { Domberger et al., } 2000\end{array}$} & Innovativeness enhancement after outsourcing & Item 22 \\
\hline & & \\
\hline & Tore chance to engage in risk-taking new ventures & 23 \\
\hline & Proactiveness improvement because of outsourcing & Item 24 \\
\hline & The reinforcement of aggressive orientation to rivals & Item 25 \\
\hline
\end{tabular}

Table 2. Survey items excerpted from questionnaire 


\section{Validation assessment}

Assessing how well the proposed scale measures the entrepreneurial outsourcing concept, the scale validation process in this study includes the following stages: I. the assessment of constructs' dimensionality using a confirmatory factor analysis (CFA) approach with AMOS 21 (IBM, New York, USA). 2. Reliability assessment utilizing two major criteria i.e., Cronbach's $\alpha$ and composite reliability with SmartPLS 2.0 (Ringle et al., 2005). 3. Construct validation in terms of convergent validity and discriminant validity with SmartPLS 2.0.

\section{Dimensionality assessment}

In this section we examine the dimensionality of constructs in our scale employing CFA. First, we checked standardized factor loadings by running the whole model with all six dimension and 25 respective items. Following the cutoff 0.4 (Hulland, 1999) for factor loadings, we excluded items with low loadings (i.e., item 4: .34, item9: .35, item 16:.37, and item 18:.38) that the results are shown in Figure 2. Checking the goodness of fit criteria (i.e., $\mathrm{X} 2 / \mathrm{df}, \mathrm{CFI}, \mathrm{GFI}, \mathrm{TLI}$, and RMSEA) after running the whole model with AMOS 21 and following the Chau's (1997) recommended cutoffs for X2/df (3.0), CFI (.90), TLI (.90), GFI (.90), and RMSEA (I.0), the results confirm the dimensionality of the 21 -item, sixdimension scale $(\mathrm{X} 2 / \mathrm{df}=\mathrm{I} .53, \mathrm{CFI}=.94, \mathrm{TLI}=.92, \mathrm{GFI}=.90$, RMSEA=.05).

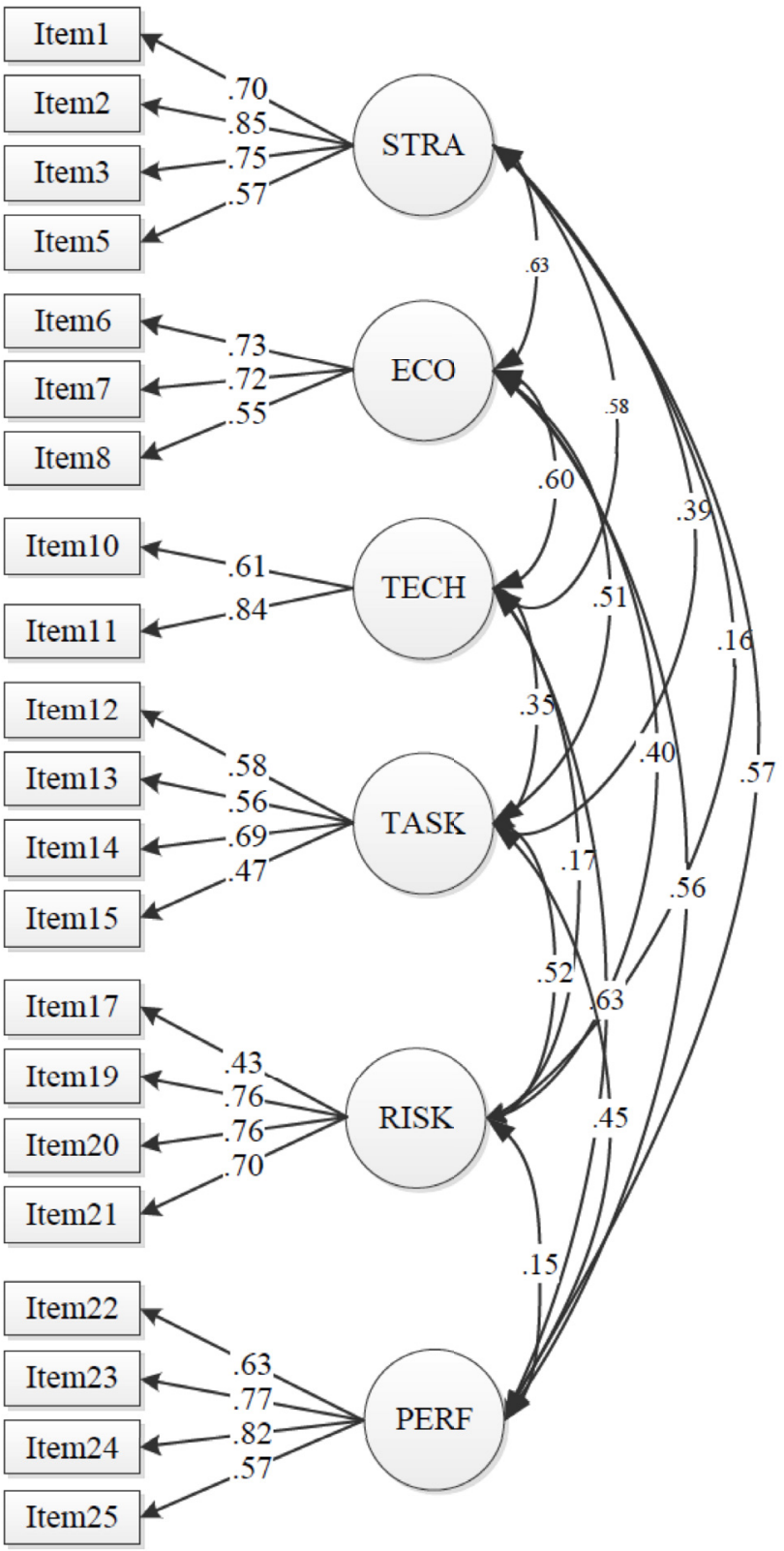

Note: STRA: Strategic factors; ECO: Economical factors;TECH: Technological factors;TASK:Task specification; RISK: Risk-relating factors; PERF: Entrepreneurial performance.

Figure 2. Confirmatory factor analysis using AMOS 21

ISSN: 07 I8-2724. (http://www.jotmi.org) 
In addition to performing CFA through a covariancebased technique with AMOS 2I, we applied CFA through a covariance-based approach (PLS-CFA) using SmartPLS 2. Regarding the fact that the results of PLS may indicate more adequacy because of some reasons such as more accuracy in small samples, non-normal data, focus on prediction, exploratory research, theory development, and theory testing (Ringle et al., 20I2), we determined to perform factor analysis via PLS. Following the procedure proposed by Agarwal and Karahanna (2000), our results from PLS-CFA indicated more adequate factor loading as displayed in Table 3 suggesting no need to deletion of items, consequently confirming the dimensionality of our proposed 25 -item, sixdimension scale.

\section{Reliability evaluation}

Assessing internal consistency of our scale, we checked the alpha (Cronbach, 195I) values and composite reliability (CR) (Fornell and Larker, 198I) of the six latent variables. Considering the threshold of 0.7 for alpha and CR (Nunnally, 1978), our results from SmartPLS 2 shown in Table 3 indicate an adequate reliability for the proposed scale. Note that according to the few numbers of our constructs, some alpha values are slightly lower than 0.7 that is acceptable because they still exceed the cutoff 0.6 suggested by moss et al. (1998) in cases of smaller number of items.

\begin{tabular}{|l|l|l|l|l|l|}
\hline Items & Latent variables & & & & \\
\hline Item5 & Item4 & Item3 & Item2 & Item I & \\
\hline .70 & .48 & .80 & .85 & .78 & STRA \\
\hline & & ECO3 & ECO2 & ECOI & \\
\hline & & $.8 I$ & .74 & .77 & ECO \\
\hline & & PR3 & PR2 & PRI & \\
\hline & & .84 & .80 & .56 & TECH \\
\hline TASK5 & TASK4 & TASK3 & TASK2 & TASKI & \\
\hline .52 & .70 & .74 & .65 & .60 & TASK \\
\hline RISK5 & RISK4 & RISK3 & RISK2 & RISKI & \\
\hline .75 & .80 & $.8 I$ & $.5 I$ & .63 & RISK \\
\hline & PERF4 & PERF3 & PERF2 & PERFI & \\
\hline & .72 & .85 & $.8 I$ & .74 & PERF \\
\hline
\end{tabular}

Table 3. PLS confirmatory factor analysis (PLS-CFA)

\begin{tabular}{|l|l|l|l|l|}
\hline Latent Variables & No. of items & Cronbach's $\alpha$ & CR & AVE \\
\hline Strategic factors & 4 & 0.80 & 0.87 & 0.63 \\
\hline Economical factors & 3 & 0.69 & 0.82 & 0.60 \\
\hline Technological factors & 2 & 0.68 & 0.86 & 0.75 \\
\hline Task specifications & 4 & 0.78 & 0.86 & 0.60 \\
\hline Risk-relating factors & 4 & 0.75 & 0.84 & 0.58 \\
\hline Entrepreneurial performance & 4 & 0.65 & 0.79 & 0.49 \\
\hline
\end{tabular}

Table 3. Reliability and convergent validity assessment

ISSN: 07 I8-2724. (http://www.jotmi.org) 


\section{Construct validation}

After assessing the dimensionality as well as reliability, we evaluated the construct validity confirming theoretically derived predictions about relations among constructs. To this, first, we assessed convergent validity via the average variance extracted (AVE) values in order to check the consistency that multiple items exhibit in measuring their respective constructs. Following the threshold of 0.5 (Fornell and Larker, | 98I) for AVEs, the results as depicted in Table 3, confirm the sufficient convergent validity of our scale.

In addition to convergent validity, we assessed the discriminant validity of our scale following the procedure recommended by Fornell and Larker (198I).AS can be seen in Table 4, the total variances shared between each latent variable and their relevant measures (i.e., the square roots of constructs' AVEs located in diagonal elements of the matrix) significantly exceed the correlations between constructs (i.e., coefficients located in lower left off-diagonal elements of the matrix) indicating an adequacy for discriminant validity in our scale.

\section{Discussion and conclusion}

The research findings regarding the identification of the dimensions of entrepreneurial outsourcing and relevant indicators to build a measurement tool demonstrated that six dimensions of strategic factors, economical factors, technological factors, risk, task specifications, and entrepreneurial performance determine entrepreneurial outsourcing construct well. Particularly, data analysis indicated adequate extents of constructs' multidimensionality, reliability or internal consistency, as well as convergent and discriminant validity.
Interpreting the results of this study, the dimensions of the proposed entrepreneurial outsourcing scale together with indicators are described briefly in the following.

The strategic factors dimension as the first identified dimension for measuring entrepreneurial coalition concerns with focusing on core competencies and the alignment level of the outsourcing activities with partners' missions and strategic goals. Strategic factors were measured with multiple indicators connected to following matters: I) the possibility of greater focus on operating core functions due to the assignment of subsidiary activities to outsourcing partners, 2) greater access of the customer partner in outsourcing to more qualified personnel in subsidiary activities with the help of service providers, 3) the possibility of increasing the flexibility of the client partner against environmental changes with the help and guidance of the service provider, 4) The possibility of transferring sectors and activities that are troublesome and difficult to control, and 5) the possibility of better respond to customer demands due to getting help from supplier companies to meet customer needs.

The economic factors dimension, as the second effective factor on entrepreneurial coalition, concerns with comparing internal costs of activities with outsourcing costs. Savings in expenses is one of the most important factors for outsourcing, which encourage organizations to outsource their activities. Accordingly, economical factors were measured with multiple indicators covering following major issues: I) reducing costs due to lack of the need to recruit labor in assigned activities, 2) reducing costs due to lack of the need to use new technologies in assigned activities, and 3 ) the possibility of increasing the control of the client partner on the costs of operating the outsourced activities.

\begin{tabular}{|l|l|l|l|l|l|l|}
\hline PERF & RISK & TASK & TECH & ECO & STRA & Constructs \\
\hline & & & & & .79 & STRA \\
\hline & & & & .78 & .46 & ECO \\
\hline & & & .87 & .43 & .48 & TECH \\
\hline & & .78 & .28 & .37 & .35 & TASK \\
\hline & .76 & .42 & .09 & .25 & .09 & RISK \\
\hline .70 & .06 & .33 & .49 & .43 & .49 & PERF \\
\hline
\end{tabular}

Table 4. Discriminant validity assessment 
The technological factors dimension is the third identified dimension for the measurement of entrepreneurial outsourcing concept. Technological factors highlight the changes in technology as one of the main motivations for outsourcing. Technological factors were measured with multiple indicators pointing out important relating issues as follows: I) reducing the risk of using new and sophisticated technologies due to cooperation with suppliers or service providers in outsourcing, 2) access to new technologies with the assistance of suppliers in outsourcing, and 3) technology transfer between customer and supplier partners in outsourcing collaboration.

The specifications of outsourced activities, as the fourth dimension of the entrepreneurial outsourcing scale, focus on substantial features of activities that should be considered for outsourcing. Processes or tasks that do not play a key role in organization's core competencies are preferred processes for outsourcing. Performing all processes within the organization requires resources, expertise, and consideration that are not often available in the organization sufficiently and should be provided from an external source. This dimension was measured with indicators highlighting the following matters: I) The lower importance of outsourced activity at client's core competencies, 2) the possibility of isolation and separation of transferable activities from other activities, 3) repetitive and standard activities that can be transferred to external sources, 4 ) the degree of specialization in activities for outsourcing, and 5) Level of expertise of the service provider in operating outsourced activities.

Risk in outsourcing, as the fifth dimension of entrepreneurial outsourcing scale, refers to threats that partners are faced in the outsourcing process. Damages that may arise in the occurrence of failure of outsourcing highlight the underlying role of risk factors in measuring the entrepreneurial outsourcing scale. Outsourcing risk related factors in the proposed measurement tool were introduced with indicators connected to following matters: I) the risk of losing the intellectual capital of the client partner in outsourcing such as patented inventions, 2) the development of dependence on supplier companies in outsourcing, 3) loss of control over outsourced activities on behalf of the customer company, 4) the possibility of breach of contract and outsourcing agreements by the client or supplier partner, and 5) limited number of suppliers for assigning activities to them.

Outsourcing entrepreneurial performance, as the sixth dimension of the scale, refers to the variables that determine the success or failure rate of outsourcing from the perspective of corporate entrepreneurship. Since the performance of outsourcing is a sign of the realization of common goals for outsourcing partners, its measurement is remarkably important for the partners' managers. Success in this agreement reflects in positive tangible and non-tangible outcomes such as market growth, increasing revenues and reducing costs, which eventually lead to the creation of value for outsourcing partners. On the other hand, since the situation of entrepreneurship in organizations has a key role in determining performance, outsourcing entrepreneurial performance should be considered with entrepreneurial factors. Therefore, entrepreneurial performance was introduced in this study and measured with indicators around the following issues: I) innovativeness enhancement of the client partner in terms of developing new products/ services or applying new process after outsourcing, 2) increasing competitive capacity of the customer company due to cooperation with supplier companies in outsourcing, 3) more pioneering of the client partner in markets due to taking competitive advantages of supplier partners through outsourcing, and 4) the possibility of the client company entrance into new ventures due to the outsourcing of less important activities to external sources.

To conclude, this research has disclosed a literature review on the outsourcing from the perspective of entrepreneurship. Extending entrepreneurship into the domain of outsourcing, we focused on studying entrepreneurial outsourcing concept both in theory and practice. The proposed scale for measuring entrepreneurial outsourcing consists of 6 dimensions and 25 items that according to our results, explain the concept of entrepreneurial outsourcing well. The new measurement tool can be used by both scholars and executives. For scholars and practitioners the scale can render the outsourcing literature rich in the realm of entrepreneurship. Also, executives including partners' managers in outsourcing agreements can monitor their relationship quality as well as their performance particularly with a focus on corporate entrepreneurship. 


\section{References}

AGARWAL, R., Karahanna, E. (2000). Time flies when you're having fun: cognitive absorption and beliefs about information technology usage I, MIS quarterly, 24(4), 665-694.

ARNOLD, U. (2000). New dimensions of outsourcing: a combination of transaction cost economics and the core competencies concept. European Journal of Purchasing \& Supply Management, 6(I), 23-29.

BALACHANDRA, R. (2005). Outsourcing R\&D. Institute for Global Innovation Management.

BALOH, P., Jha, S., Awazu, Y. (2008). Building strategic partnerships for managing innovation outsourcing. Strategic Outsourcing, An International Journal, I (2), I00-2I.

BROWN, D. (2008). It's good to be green: environmentallyfriendly credentials are influencing business outsourcing decisions. Strategic Outsourcing, An International Journal, I(I), 87-95.

BUSI, M., Mclvor, R. (2008). Setting the outsourcing research agenda: the top- 10 most urgent outsourcing areas. Strategic Outsourcing: An International Journal, I(3), I85- 197.

CARNAHAN, S., Somaya, D. (2013). Alumni Effects and Relational Advantage:The Impact on Outsourcing when Your Buyer Hires Employees from Your Competitors. Academy of Management Journal. http://amj.aom.org/content/ early/2013/0I/I0/amj.20II.0089.short, [Accessed January $10,2013]$

CESARONI, F. (2004).Technological outsourcing and product diversification: do markets for technology affect firms' strategies?. Research Policy, 33(10), I547-I564.

CHANG, Y. B., Gurbaxani, V. (20I2). Information technology outsourcing, knowledge transfer, and firm productivity: An empirical analysis. MIS Quarterly, 36(4), 1043-1053.

CHAU, P. Y. (1997) Reexamining a model for evaluating information center success using a structural equation modeling approach. Decision Sciences, 28(2), 309-334.

COASE, R. H. (1937). The nature of the firm. economica, 4(16), 386-405.

COVIN, J., Miles, M. (2006). Corporate entrepreneurship and the pursuit of competitive advantage. Corporate Entrepreneurship and Growth, Edward Elgar Publishing Ltd, Zahra, S. (ed), Indianapolis, 47-63.
COX, A. (200I). Understanding buyer and supplier power: a framework for procurement and supply competence. Journal of Supply Chain Management, 37(2), 8-I5.

CRONBACH, L. J. (195I). Coefficient alpha and the internal structure of tests. Psychometrika, 16(3), 297-334.

DE PABLOS, P. O. (20/3). Business, Technology, and Knowledge Management in Asia: Trends and Innovations. Business Science Reference.

DESS, G. G., Lumpkin, G.T. (2005).The role of entrepreneurial orientation in stimulating effective corporate entrepreneurship. The Academy of Management Executive, 19(I) 147-I56.

DIBBERN, J., Goles, T., Hirschheim, R., Jayatilaka, B. (2004). Information systems outsourcing: a survey and analysis of the literature. ACM SIGMIS Database, 35(4), 6- 102.

DOMBERGER, S., Fernandez, P., Fiebig, D. G. (2000). Modelling the price, performance and contract characteristics of IT outsourcing. Journal of Information Technology, 15(2), 107118.

EMBLETON, P. R., Wright, P. C. (1998). A practical guide to successful outsourcing. Empowerment in Organizations, 6(3), 94-106.

FEENSTRA, R. C., Hanson, G. H. (1999). The impact of outsourcing and high-technology capital on wages: estimates for the United States, 1979-1990. The Quarterly Journal of Economics, I I4(3), 907-940.

FORNELL, C., Larcker, D. F. (198I). Evaluating structural equation models with unobservable variables and measurement error. Journal of marketing research, 39-50.

GAVIOUS, A., Rabinowitz, G. (2003). Optimal knowledge outsourcing model. Omega, 3I (6), 45 I-457.

GREAVER, M. F. (1999). Strategic outsourcing: a structured approach to outsourcing decisions and initiatives. Amacom.

GROVER, V., Cheon, M. J., Teng, J. T. (1994). A descriptive study on the outsourcing of information systems functions. Information \& Management, 27(I), 33-44.

HAFEEZ, K., Essmail, E. A. (2007). Evaluating organization core competences and associated personal competencies using analytical hierarchy process. Management Research News, 30(8), 530-547. 
HALL, R. (2000). Outsourcing, Contracting-out and Labour Hire: Implications for Human Resource Development in Australian Organizations. Asia Pacific Journal of Human Resources, 38(2), 23-4I.

HAN, C., Dresner, M. Windle, R.J. (2008). Impact of global sourcing and exports on US manufacturing inventories. International Journal of Physical Distribution and Logistics Management, 38(6) 475-94.

HARLAND, C., Night, L., Lamming, R. Walker, H. (2008). Outsourcing: assessing the risks and benefits for organizations, sectors and nations. International Journal of Operations and Production Management, 25(9), 83 I-50.

HOLCOMB, T. R., Hitt, M. A. (2007). Toward a model of strategic outsourcing. Journal of operations management, 25(2), 464-48I.

HULLAND, J. (1999). Use of partial least squares (PLS) in strategic management research, A review of four recent studies, Strategic Management Journal, 20(2), I 95-204.

JAVALGI, R. R. G., Dixit, A., Scherer, R. F. (2009). Outsourcing to emerging markets: theoretical perspectives and policy implications. Journal of International Management, I5(2), 156-168.

JOHNSON, J. L., Umesh, U. N. (2002). The interplay of task allocation patterns and governance mechanisms in industrial distribution channels. Industrial Marketing Management, $3 \mathrm{I}(8), 665-678$.

KAKUMANU, P., Portanova, A. (2006). Outsourcing: Its benefits, drawbacks and other related issues. Journal of American Academy of Business, 9(2), I-7.

KALAIGNANAM, K., Varadarajan, R. (20I2). Offshore outsourcing of customer relationship management: conceptual model and propositions. Journal of the Academy of Marketing Science, 40(2), 347-363.

KAMEL, S. (Ed.). (2006). Electronic business in developing countries: opportunities and challenges. IGI Global.

KANG, M., Wu, X., Hong, P., Park, Y. (20I2). Aligning organizational control practices with competitive outsourcing performance. Journal of Business Research, 65(8), II95-120I.

KOTABE, M., Mol, M. J., Murray, J. Y. (2008). Outsourcing, performance, and the role of e-commerce: $A$ dynamic perspective. Industrial Marketing Management, 37(I), 37-45.
LEAVY, B. (2004). Outsourcing strategies: opportunities and risks. Strategy \& Leadership, 32(6), 20-25.

LEE, J. N., Huynh, M. Q., Kwok, R. C. W., Pi, S. M. (2003). IT outsourcing evolution---: past, present, and future. Communications of the ACM, 46(5), 84-89.

MADSEN, E. S., Riis, J. O., Waehrens, B. V. (2008), The knowledge dimension of manufacturing transfers - a method for identifying hidden knowledge. Strategic Outsourcing, An International Journal, I(3), 198-209.

MARTINEZ-NOYA, A., Garcia-Canal, E., Guillen, M. F. (20I3). R\&D Outsourcing and the Effectiveness of Intangible Investments: Is Proprietary Core Knowledge Walking out of the Door?. Journal of Management Studies, 50(I), 67-9I.

MASKELL, P., Pedersen, T., Petersen, B., Dick-Nielsen, J. (2007). Learning paths to offshore outsourcing: from cost reduction to knowledge seeking. Industry and Innovation, I4(3), 239-257.

MCIVOR, R. (2005). The outsourcing process: strategies for evaluation and management. Cambridge University Press.

MISCIMARRA, P.A., Schwartz, K. D. (1997). Frozen in timeThe NLRB, outsourcing, and management rights. Journal of Labor Research, I8(4), 56I-580.

MOSS, S., Prosser, H., Costello, H., Simpson, N., Patel, P., Rowe, S., ..., Hatton, C. (1998). Reliability and validity of the PASADD Checklist for detecting psychiatric disorders in adults with intellectual disability. Journal of Intellectual Disability Research, 42(2), I73-I83.

MURPHY, P. J., Wu, Z., Welsch, H., Heiser, D. R., Young, S. T., Jiang, B. (20I2). Small firm entrepreneurial outsourcing: traditional problems, nontraditional solutions. Strategic Outsourcing:An International Journal, 5(3), 248-275.

NADKARNI, S., Herrmann, P. O. L. (20I0). CEO personality, strategic flexibility, and firm performance: The case of the Indian business process outsourcing industry. Academy of Management Journal, 53(5), I050-I073.

NDUBISI, N. O. (20I3). Role of gender in conflict handling in the context of outsourcing service marketing. Psychology \& Marketing, 30(I), 26-35.

NUNNALLY, J. C. (1978). Psychometric Theory (2nd ed.). McGraw-Hill, New York. 
RAWLEY,E.,Simcoe,T.S.(2010).Diversification, diseconomies of scope, and vertical contracting: Evidence from the taxicab industry. Management Science, 56(9), I 534-I550.

RINGLE, C., Sarstedt, M., Straub, D. (20/2).A Critical Look at the Use of PLS-SEM in MIS Quarterly. MIS Quarterly (MISQ), 36(I), iii-8.

RINGLE, C. M., Wende, S., Will, A. (2005). SmartPLS 2.0 (beta). http://www.smartpls.de.

SAATY, T. L., Vargas, L. G. (20/3). Outsourcing a Firm's Application Development Group. Decision Making with the Analytic Network Process. 195, 93-II 7.

TSAI, M. C., Lai, K. H., Lloyd, A. E., Lin, H. J. (20I2). The dark side of logistics outsourcing-unraveling the potential risks leading to failed relationships. Transportation Research Part E: Logistics and Transportation Review, 48(I), I78-189.

WILLEMS, T., Van Dooren, W. (20ll). Lost in diffusion? How collaborative arrangements lead to an accountability paradox. International Review of Administrative Sciences, 77(3), 505-530.

WILLIAMSON, O. E. (1979). Transaction-cost economics: the governance of contractual relations. Journal of law and economics, 22(2), 233-26I.

YANG, D. H., Kim, S., Nam, C., Min, J.W. (2007). Developing a decision model for business process outsourcing. Computers \& Operations Research, 34(I2), 3769-3778.

YEBOAH,A. (20I3). The Relationship between Outsourcing and Organizational Performance. European Journal of Business and Management, 5(2), I- I2.

ZHENG, W., Yang, B. Mclean, G. N. (2009). Linking organizational culture, atructure, strategy and organizational effectiveness: the mediating role of Knowledge management. journal of business research, 9, 65-76. 